\title{
CubeSat formation architecture for small space debris surveillance and orbit determination
}

\author{
A. A. Afanaseva, Post-Graduate Student, orcid.org/0000-0001-7503-9696, anton.afanasev@skoltech.ru \\ S. N. Biktimirova, Post-Graduate Student, orcid.org/0000-0003-0969-0944 \\ askolkovo Institute of Science and Technology, bld. 1, 30, Bolshoy Boulevard, 121205, Moscow, \\ Russian Federation
}

\begin{abstract}
Introduction: Satellites which face space debris cannot track it throughout the whole orbit due to natural limitations of their optical sensors, sush as field of view, Earth occultation, or solar illumination. Besides, the time of continuous observations is usually very short. Therefore, we are trying to offer the most effective configuration of optical sensors in order to provide short-arc tracking of a target piece of debris, using a scalable Extended Information Filter. Purpose: The best scenario for short-arc tracking of a space debris orbit using multipoint optical sensors. Results: We have found optimal configurations for groups of satellites with optical sensors which move along a sun-synchronous orbit. Debris orbit determination using an Extended Information Filter and measurements from multipoint sensors was simulated, and mean squared errors of the target's position were calculated. Based on the simulation results for variouos configurations, inter-satellite distances and measurement time, the most reliable scenario (four satellites in tetrahedral configuration) was found and recommended for practical use in short-arc debris tracking.
\end{abstract}

Keywords - space debris, short-arc tracking, sun-synchronous orbit, relative motion, extended information filter.

For citation: Afanasev A. A., Biktimirov S. N. CubeSat formation architecture for small space debris surveillance and orbit determination. Informatsionno-upravliaiushchie sistemy [Information and Control Systems], 2021, no. 4, pp. 37-46. doi:10.31799/16848853-2021-4-37-46

\section{Introduction}

Space Situational Awareness (SSA) is the knowledge and characterization of space objects and their operational environment to support safe, stable, and sustainable space activities. The problems arising in the context of SSA have become a significant concern for the space community, because of expanding growth in numbers of satellite systems and operators in Earth orbits, corresponding growth in the existing space debris population, and interaction between space systems and space debris populations, which necessitates collision risk assessment and general measures to mitigate the debris problem before it develops into what is termed Kessler syndrome [1]. Presently, space debris are monitored and catalogued using ground-based optical telescopes and radars, which allow obtaining comprehensive knowledge of all objects larger than $10 \mathrm{~cm}$ in size and their orbits. However, it is estimated that only about $4 \%$ of the objects in low Earth orbit (LEO) sized one centimeter and larger are contained in the public space object catalog [2]. In particular, it is reported that the space debris density is very high in sun-synchronous orbits (SSO), which is very popular among satellite systems operators.

This study considers a number of formation-flying architectures to perform space-based optical observations for on-request orbit determination of smaller (1 to $10 \mathrm{~cm}$ in size) space debris objects in SSO. Prior research indicates that the on-board sen- sors can be advantageous in SSA programs, because they are not interrupted by the daylight, and they are not characterized by the scattering, diffractions, aberrations and turbulences in the atmosphere [3]. In recent years, a number of studies have been carried out towards analyzing different aspects of spaceborne debris surveillance missions. [4] proposed space-based optical instruments and discussed how the existing knowledge gap in the space debris population in the millimetre and centimetre regime may be closed by means of a passive optical instrument. [5] discusses how a MEO satellite can potentially detect debris objects in GEO. [6] proposes a method for accurate orbit determination and prediction using short-arc tracking data. Various techniques for space debris orbit determination based on short-arc data are also discussed in [7, 8]. A multi-spacecraft formation approach to space-debris monitoring is developed in [3, 9], these papers propose a networking system of spacecraft that dynamically processes distributed measurements and recovers the debris object's orbits. Such systems allow processing multipoint measurements and exhibit collective behavior are discussed in other space applications [10], and their usage becomes indispensable for debris tracking or orbit acquisition tasks, because they cannot be carried out by a single device. The idea of cooperative object tracking using space-based optical sensors is also developed in [11, 12]. Further studies [13] go as far as proposing large constellations of spacecraft for global space debris monitoring. 
Understanding the inevitable use of satellite formations for accurate small debris object tracking and their orbit determination, we carry out a comparative analysis of different formation architectures, comprising different number of spacecraft (two to four), and assuming different orbital configurations (from the simplest train-like formation, through moderately complex general-circular-orbit (GCO) formation, and ending up with the most complex tetrahedral formation). We assume that the formations are deployed into a circular sun-synchronous orbit at $700 \mathrm{~km}$ altitude and each spacecraft carries an optical payload to track the debris objects. We discuss the observation conditions and select an orbit close to the terminator plane. We then analyze a construction of an extended information filter to process the multipoint measurements obtained by the formation spacecraft and analyze its orbit determination accuracy taking into account the payload constraints and depending on such systems parameters as the formation type, number of spacecraft in a formation, and intersatellite distances.

\section{Mission design}

Let us consider a circular Sun-synchronous orbit passing near to the Earth terminator line as a reference orbit for space debris observation with the aid of a small formation flying satellites. We use these kinds of reference orbits because it allows observing space debris using optical cameras at any point on orbit. For numerical simulations of the proposed algorithms let us consider the circular SSO orbits with $700 \mathrm{~km}$ altitude. Thus, the inclination $i$ of the reference orbit can be found from the expression for secular rate of right ascension of ascending node

$$
\dot{\Omega}=-\frac{3 n R_{\oplus}^{2} J_{2}}{2 R_{\mathrm{orb}}^{2}} \cos i
$$

where $R_{\oplus} \approx 6371 \mathrm{~km}$ is the radius of the Earth; $J_{2} \approx 0.00108263$ is the second order zonal harmonic of the Earth gravitational potential; $R_{\text {orb }}$ is the reference orbit radius, $n=\sqrt{\frac{\mu}{R_{\mathrm{orb}}^{3}}}$ is the orbit mean motion, $\mu \approx 3.986 \times 10^{14} \mathrm{~m}^{3} / \mathrm{s}^{2}$ is the standard gravitational parameter of the Earth. From the expression (1) the inclination of the corresponding SSO orbit is equal to 98.18 degrees.

Finally, we should find such a right ascension of ascending node (RAAN) $\Omega$ that will orient the orbit close to the terminator line. Let us define the RAAN $\Omega$ in way that will align projection of the orbit's unit angular momentum vector $\mathbf{e}_{h}$ onto the $x y$-plane along the projection of the Sun position vector $\mathbf{R}_{\text {Sun }}$ onto the $x y$-plane. Let us consider the simulation start epoch 1st January, 2022. The corresponding Sun position vector, given in Earth-Centered Inertial coordinates, is equal to $\mathbf{R}_{\text {Sun }}=[26127801,-132825709.3,-57579560.5]^{\mathrm{T}} \mathrm{m}$. This yields RAAN $\Omega=11.13^{\circ}$. Fig. 1 depicts the reference orbit, built by Systems Toolkit software.

Reference orbit parameters at epoch Jan 1, 2022, 00:00:00 UTC:

- SMA, km - 7071;

- Eccentricity - 0;

- Inclination, deg - 98.18;

- RAAN, deg - 11.13;

- Argument of perigee (AOP), deg - 0;

- True anomaly (TA), deg - 0 .

To demonstrate the proposed algorithms performance, we consider 3 common satellite formation configuration types such as train, GCO, and

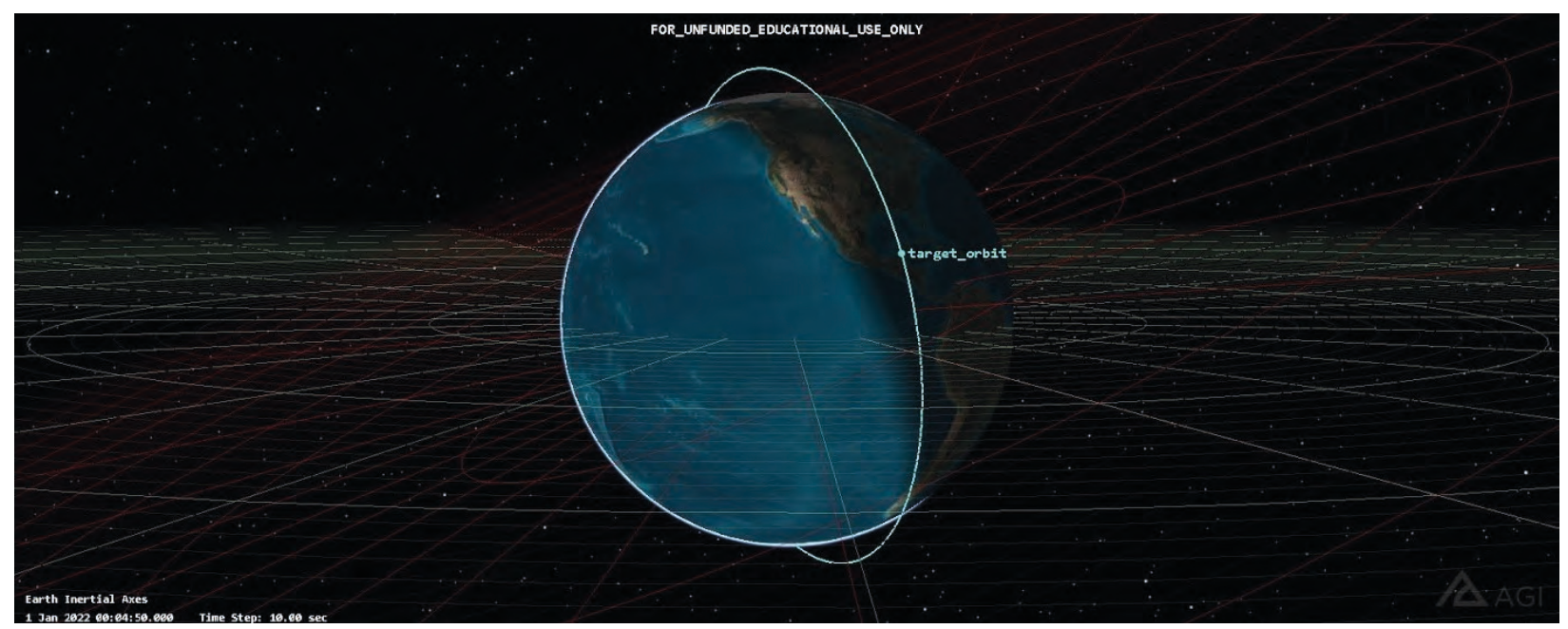

- Fig. 1. Systems Toolkit simulation of the target orbit 
tetrahedron formation. For trade-off analysis we will also test each orbital configuration with different triangulation bases. In order to design the formations' orbital configurations, we employ the Hill - Clohessy - Wiltshire (HCW) equations that describe linearized relative motion dynamics for a couple of satellites at near-circular orbits. The HCW equations can be written as follows:

$$
\begin{gathered}
\ddot{x}+n \dot{z}=\mathbf{u}_{x} ; \\
\ddot{y}+n \quad y=\mathbf{u}_{y} ; \\
\ddot{z}-2 n \dot{x}-3 n \quad z=\mathbf{u}_{z},
\end{gathered}
$$

where $\mathbf{u}$ is unit force vector acting on a satellite; $x$, $y, z$ are satellite position vector components given in the orbital reference frame (along track, normal and radial respectively).

The HCW equations (2) admit periodic analytical solutions in case of free motion that can be written in the following form $[14,15]$ :

$$
\begin{gathered}
x(t)=c_{1} \cos (n t+\alpha)+c_{3} ; \\
y(t)=c_{2} \sin (n t+\beta) ; \\
z(t)=\frac{c_{1}}{2} \sin (n t+\alpha),
\end{gathered}
$$

where constants $c_{1}, c_{2}, c_{3}, \alpha, \beta$ are used to define the initial conditions of the relative motion.

The orbital configurations used in the study are defined in Table 1. Parameter $\rho$ defines a triangulation base. In the numerical simulation we use three different values for $\rho=1,5,10 \mathrm{~km}$ [10]. Fig. 2, $a-c$ depict resulting orbital configurations from (3).

\section{Optical system dynamics}

Let's consider the Earth-Centered Inertial reference frame and express the orbital dynamics of the target debris with radius-vector $\mathbf{r}$ and velocity $\mathbf{v}$ in this frame [16]:

$$
\left(\begin{array}{l}
\mathbf{r} \\
\mathbf{v}
\end{array}\right)=\left(\begin{array}{l}
\mathbf{v} \\
\mathbf{a}_{c}+\mathbf{a}_{J}
\end{array}\right)+\left(\begin{array}{l}
\eta_{\mathbf{v}} \\
\eta_{\mathbf{a}}
\end{array}\right)
$$

where

\begin{tabular}{|c|c|c|c|c|c|}
\hline Satellite № & $c_{1}$ & $c_{2}$ & $c_{3}$ & $\alpha$ & $\beta$ \\
\hline \multicolumn{6}{|c|}{ Train formation } \\
\hline 1 & 0 & 0 & 0 & 0 & 0 \\
\hline 2 & 0 & 0 & $\rho$ & 0 & 0 \\
\hline 3 & 0 & 0 & $-\rho$ & 0 & 0 \\
\hline \multicolumn{6}{|c|}{ GCO formation } \\
\hline 1 & 0 & 0 & 0 & 0 & 0 \\
\hline 2 & $\rho$ & $\sqrt{3} \rho / 2$ & 0 & 0 & 0 \\
\hline 3 & $\rho$ & $\sqrt{3} \rho / 2$ & 0 & $\pi$ & $\pi$ \\
\hline \multicolumn{6}{|c|}{ Tetrahedron } \\
\hline 1 & 0 & 0 & 0 & 0 & 0 \\
\hline 2 & $2 \rho / 5$ & 0 & $2 \rho \sqrt{5 / 3}$ & 0 & 0 \\
\hline 3 & $2 \rho$ & $\rho \sqrt{5}$ & $\rho \sqrt{5 / 3}$ & $-\arctan (1 / \sqrt{2})$ & $\arctan (\sqrt{2})-\pi$ \\
\hline 4 & $2 \rho$ & $\rho \sqrt{5}$ & $\rho \sqrt{5 / 3}$ & $\arctan (1 / \sqrt{2})$ & $-\arctan (\sqrt{2})$ \\
\hline
\end{tabular}

$$
\mathbf{a}_{c}=-\mu \frac{\mathbf{r}}{r^{3}} ; \quad \mathbf{a}_{J_{2}}=\frac{3}{2} J_{2}\left(\frac{R_{\oplus}}{r}\right)^{2}\left(\frac{\mu}{r^{3}}\right)\left(\begin{array}{c}
x\left(5 \frac{z^{2}}{r^{2}}-1\right) \\
y\left(5 \frac{z^{2}}{r^{2}}-1\right) \\
z\left(5 \frac{z^{2}}{r^{2}}-3\right)
\end{array}\right),
$$

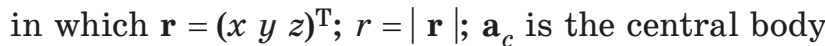
acceleration; is the acceleration from $J_{2}$ nonspherical perturbation, and process Gaussian noises $\eta_{\mathbf{v}} \sim \mathcal{N}\left(\mathbf{0}, \sigma_{\mathbf{v}}^{2} \mathbf{I}_{3 \times 3}\right)$ and $\eta_{\mathbf{a}} \sim \mathcal{N}\left(\mathbf{0}, \sigma_{\mathbf{a}}^{2} \mathbf{I}_{3 \times 3}\right)$

- Table 1. Initial conditions 
a)
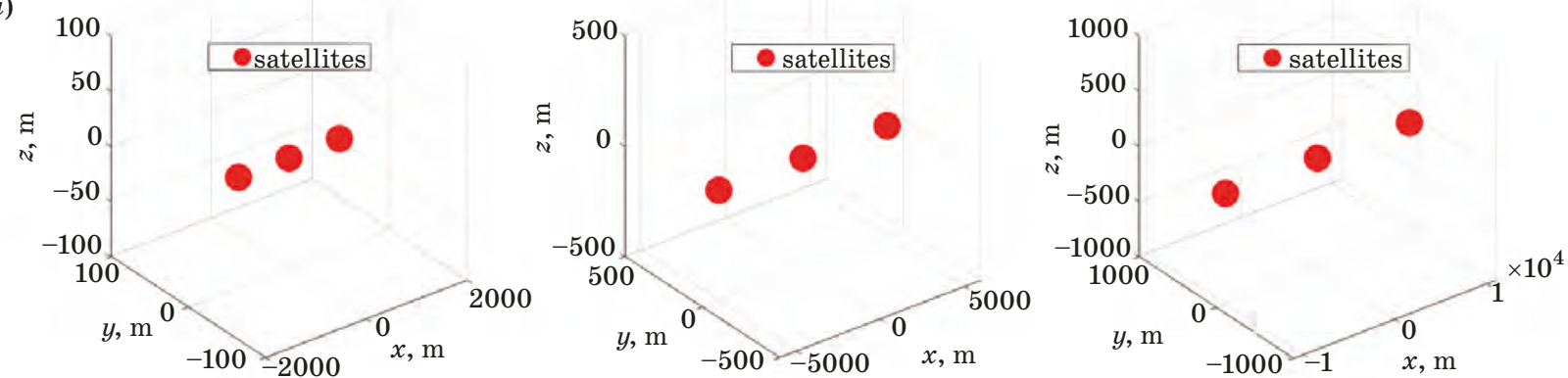

b)
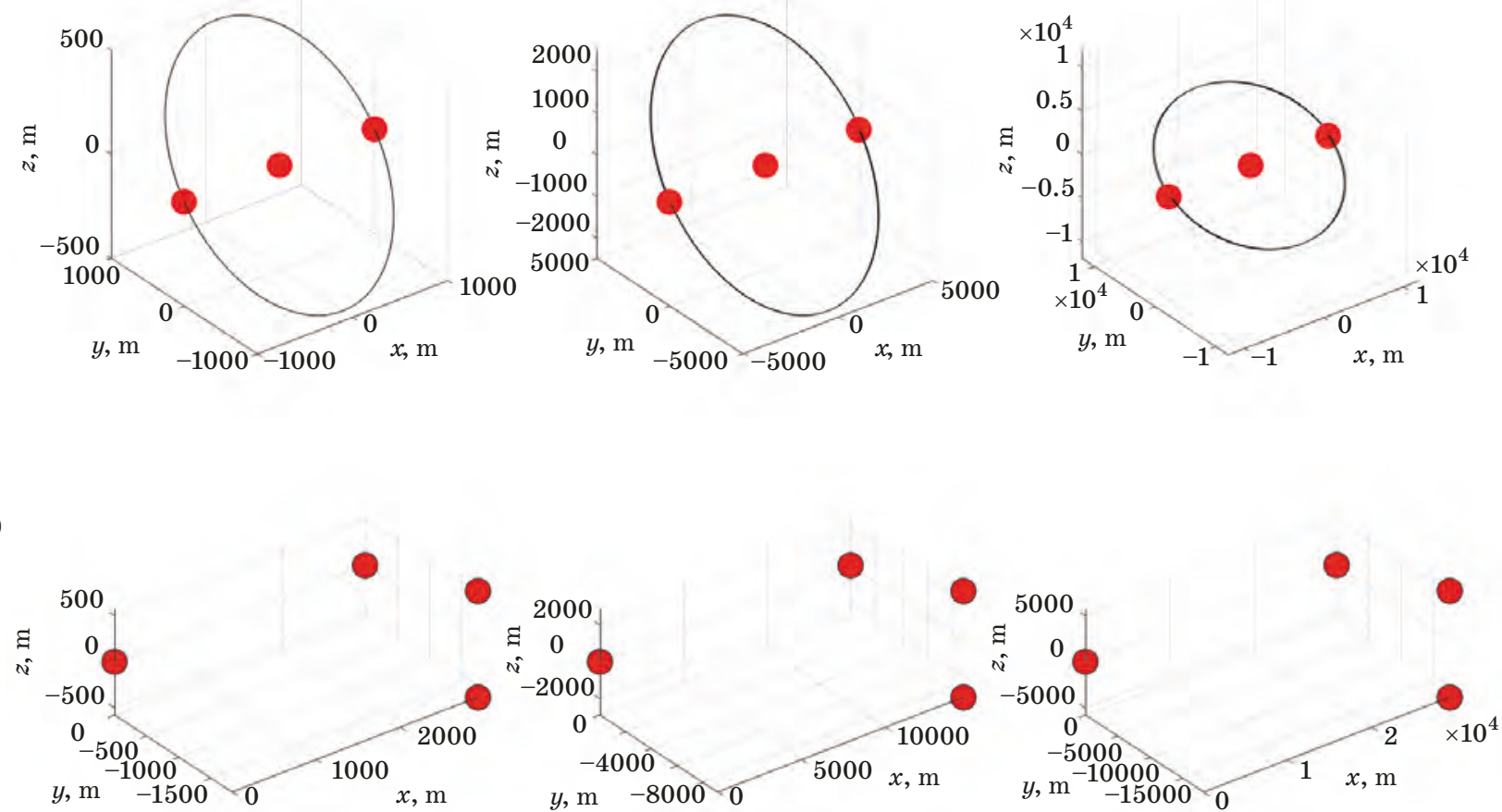

- Fig. 2. Train $(a)$, GCO $(b)$ and tetrahedron $(c)$ formations: left $-\rho=1 \mathrm{~km}$; centered $-\rho=5 \mathrm{~km}$; on the right $\rho=10 \mathrm{~km}$

of the velocity and acceleration with zero mean and corresponding standard deviations $\sigma_{\mathbf{v}}$ and $\sigma_{\mathbf{a}}$ respectively, $\mathbf{I}_{3 \times 3}$ is the identity matrix of size 3 .

The position of the target is measures with two angles - elevation $\theta$ and azimuth $\varphi$, which then converted into primary parameters of the debris orbit, according to the data about background stars on the image. The model of observations is following:

$$
\begin{gathered}
\varphi=\arctan \left(\frac{y-y_{i}}{x-x_{i}}\right)+\eta_{\varphi} ; \\
\theta=\arctan \left(\frac{z-z_{i}}{\sqrt{\left(x-x_{i}\right)^{2}+\left(y-y_{i}\right)^{2}}}\right)+\eta_{\theta},
\end{gathered}
$$

where $\left(x_{i} y_{i} z_{i}\right)^{\mathrm{T}}$ is the position of the $i$-th sensor in Earth-Centered Inertial; $\eta_{\varphi}, \eta_{\theta} \sim \mathcal{N}\left(0, \sigma_{\text {meas }}^{2}\right)$ are measurement Gaussian noises with standard deviation $\sigma_{\text {meas }}$ and zero mean [17].

\section{Target position estimation with Extended Information Filter}

The state-space vector is $\mathbf{X}=(\mathbf{r} \mathbf{v})^{\mathrm{T}}$, its covariance matrix is $\mathbf{P}$, measurement vector is $\mathbf{z}=(\varphi \theta)^{\mathrm{T}}$. The prediction for estimating the value of statespace vector in the next time-step is given by the equation (4): $\mathbf{X}_{k}=f\left(\mathbf{X}_{k-1}\right)+\left(\eta_{\mathbf{v}} \eta_{\mathbf{a}}\right)^{\mathrm{T}}$ with noise covariance matrix $\mathbf{Q}$ (identical for all $k$ ). 
Taking Jacobian of the function $f$ gives evolution matrix:

$$
\mathbf{F}=\left(\begin{array}{cccccc}
0 & 0 & 0 & 1 & 0 & 0 \\
0 & 0 & 0 & 0 & 1 & 0 \\
0 & 0 & 0 & 0 & 0 & 1 \\
F_{1}^{c}+F_{2}^{c}(x, x)+F_{1}^{J_{2}}(x) & F_{2}^{c}(x, y)+F_{3}^{J_{2}} & F_{2}^{c}(x, z)+F_{4}^{J_{2}}(x) & 0 & 0 & 0 \\
F_{2}^{c}(y, x)+F_{3}^{J_{2}} & F_{1}^{c}+F_{2}^{c}(y, y)+F_{1}^{J_{2}}(y) & F_{2}^{c}(y, z)+F_{4}^{J_{2}}(y) & 0 & 0 & 0 \\
F_{2}^{c}(z, x)+F_{4}^{J_{2}}(x) & F_{2}^{c}(z, y)+F_{4}^{J_{2}}(y) & F_{1}^{c}+F_{2}^{c}(z, z)+F_{2}^{J_{2}} & 0 & 0 & 0
\end{array}\right),
$$

where

$$
\begin{gathered}
F_{1}^{c}=-\frac{\mu}{r^{3}} ; F_{2}^{c}\left(\operatorname{coord}_{1}, \operatorname{coord}_{2}\right)=\frac{3 \mu \cdot \operatorname{coord}_{1} \cdot \operatorname{coord}_{2}}{r^{5}} ; \\
F_{1}^{J_{2}}(\operatorname{coord})=\frac{3 J_{2} R_{\oplus}^{2} \mu}{2 r^{5}}\left(\frac{5}{r^{2}}\left(\operatorname{coord}^{2}+z^{2}\right)-1-\frac{35 \cdot \operatorname{coord}^{2} \cdot z^{2}}{r^{4}}\right) ; \\
F_{2}^{J_{2}}=\frac{3 J_{2} R_{\oplus}^{2} \mu}{2 r^{5}}\left(\frac{30 z^{2}}{r^{2}}-3-\frac{35 z^{4}}{r^{4}}\right) ; F_{3}^{J_{2}}=\frac{15 J_{2} R_{\oplus}^{2} \mu x y}{2 r^{7}}\left(1-\frac{7 z^{2}}{r^{2}}\right) ; \\
F_{4}^{J_{2}}(\operatorname{coord})=\frac{15 J_{2} R_{\oplus}^{2} \mu \cdot \operatorname{coord} \cdot z}{2 r^{7}}\left(3-\frac{7 z^{2}}{r^{2}}\right) .
\end{gathered}
$$

Transition matrix $\boldsymbol{\Phi}_{k, k-1}$ is acquired from $\mathbf{F}_{k-1}$ (matrix $\mathbf{F}$ from (6) in $k-1$ time-step) as

$$
\Phi_{k, k-1}=\exp \left(\mathbf{F}_{k-1} \cdot T\right),
$$

where $T$ is the period of movement.

Similarly, measurement vector in the current time-stop for $i$-th sensor is acquired from (5): $\mathbf{z}_{k, i}=$ $=h\left(\mathbf{X}_{k, i}\right)+\left(\eta_{\varphi} \eta_{\theta}\right)^{\mathrm{T}}$ with noise covariance matrix $\Sigma$ (identical for all $k$ and $i$ ).

Observation matrix is the Jacobian of the function $h$ :

$$
\mathbf{H}_{i}=\left(\begin{array}{cccccc}
H_{\varphi, x}^{i} & H_{\varphi, y}^{i} & H_{\varphi, z}^{i} & 0 & 0 & 0 \\
H_{\theta, x}^{i} & H_{\theta, y}^{i} & H_{\theta, z}^{i} & 0 & 0 & 0
\end{array}\right)
$$

where

$$
\begin{aligned}
& H_{\varphi, x}^{i}=\frac{y_{i}-y}{\left(x_{i}-x\right)^{2}+\left(y_{i}-y\right)^{2}} ; \quad H_{\varphi, y}^{i}=\frac{x-x_{i}}{\left(x_{i}-x\right)^{2}+\left(y_{i}-y\right)^{2}} \\
& H_{\varphi, z}^{i}=0 ; \quad H_{\theta, z}^{i}=\frac{\sqrt{\left(x_{i}-x\right)^{2}+\left(y_{i}-y\right)^{2}}}{\left(x_{i}-x\right)^{2}+\left(y_{i}-y\right)^{2}+\left(z_{i}-z\right)^{2}} \\
& H_{\theta, x}^{i}=\frac{\left(x_{i}-x\right)\left(z-z_{i}\right)}{\sqrt{\left(x_{i}-x\right)^{2}+\left(y_{i}-y\right)^{2}}\left(\left(x_{i}-x\right)^{2}+\left(y_{i}-y\right)^{2}+\left(z_{i}-z\right)^{2}\right)} \\
& H_{\theta, y}^{i}=\frac{\left(y_{i}-y\right)\left(z-z_{i}\right)}{\sqrt{\left(x_{i}-x\right)^{2}+\left(y_{i}-y\right)^{2}}\left(\left(x_{i}-x\right)^{2}+\left(y_{i}-y\right)^{2}+\left(z_{i}-z\right)^{2}\right)}
\end{aligned}
$$

Using Extended Information Filter [18-21], state-space vector, transition (7), covariance matrix, information state $\mathbf{y}$ and information matrix $\mathbf{Y}$ are calculated for the predicted state: 


$$
\begin{gathered}
\mathbf{X}_{k \mid k-1}=f\left(\mathbf{X}_{k-1}\right) \\
\mathbf{P}_{k \mid k-1}=\boldsymbol{\Phi}_{k, k-1} \mathbf{P}_{k-1} \Phi_{k, k-1}^{\mathrm{T}}+\mathbf{Q} \\
\mathbf{y}_{k \mid k-1}=\mathbf{P}_{k \mid k-1}^{-1} \mathbf{X}_{k \mid k-1} \\
\mathbf{Y}_{k \mid k-1}=\mathbf{P}_{k \mid k-1}^{-1}
\end{gathered}
$$

Information step contribution $\mathbf{i}_{i}$ and information matrix contributions $\mathbf{I}_{i}$ for each sensor from the measurements (8) update is following:

$$
\begin{gathered}
\mathbf{i}_{k, i}=\mathbf{H}_{k, i}^{\mathrm{T}} \Sigma^{-1}\left(\mathbf{z}_{k, i}-h\left(\mathbf{X}_{k \mid k-1}\right)+\mathbf{H}_{k, i} \mathbf{X}_{k \mid k-1}\right) ; \\
\mathbf{I}_{k, i}=\mathbf{H}_{k, i}^{\mathrm{T}} \Sigma^{-1} \mathbf{H}_{k, i} .
\end{gathered}
$$

Update of the information state and matrix from contributions (10):

$$
\begin{aligned}
& \mathbf{y}_{k}=\mathbf{y}_{k \mid k-1}+\sum_{i=1}^{N_{\text {sens }}} \mathbf{i}_{i, k} ; \\
& \mathbf{Y}_{k}=\mathbf{Y}_{k \mid k-1}+\sum_{i=1}^{N_{\text {sens }}} \mathbf{I}_{i, k},
\end{aligned}
$$

where $N_{\text {sens }}$ is the number of CubeSats with optical sensors.

The procedure (9)-(11) is repeated over the timeframe of the simulation for the given target and sensors orbits.

\section{Constraints on the optical sensors}

It's clear that sensors will not be able to track the target debris in the majority of time due to various constraints, especially the limited field of view. Let's consider them and apply to the scenario.

1. The target should be bright enough to be observed:

$$
\begin{gathered}
-26.74-2.5 \lg \left(\frac{2}{3 \pi^{2}} A \xi\left(\sin \varphi_{i}-\varphi_{i} \cos \varphi_{i}\right)\right)+ \\
+5 \lg R_{i} \leq m_{\max },
\end{gathered}
$$

where $A$ is the target's cross-section in motion direction; $\xi$ is the target's albedo; $\varphi_{i}$ is the angle of the $i$-th sensor, adjacent to the solar phase angle (sun-target-sensor); $R_{i}$ is the distance from the $i$-th sensor to the target; $m_{\max }$ is the maximal detectable magnitude

2. Optical sensors should be oriented along with the sun:

$$
\cos \varphi_{i} \leq
$$

3. Sensors and target should be in the direct sight line above the Earth's atmosphere:

$$
\sqrt{r_{i}^{2}-\left(R_{\oplus}+h\right)^{2}}+\sqrt{r^{2}-\left(R_{\oplus}+h\right)^{2}}>R_{i},
$$

where $r_{i}$ and $r$ are the absolute values of the radiusvectors of $i$-th sensor and target respectively; $h \approx 100 \mathrm{~km}$ is the Earth's atmosphere thickness.

4. Limit of the optical sensor is represented by the sight cone with Full Width Half Maximum (FWHM) of the sensor. Thus, the target should be inside this cone:

$$
\arccos \left(\frac{\mathbf{R}_{i}}{R_{i}} \cdot \mathbf{e}_{\text {cone }}\right)<\text { FWHM, }
$$

where $\mathbf{R}_{i}$ is the vector from sensor to target; $\mathbf{e}_{\text {cone }}$ is the normalized vector, defining cone's axis.

Applying constraints (12)-(15) drastically decreases the amount of time when target debris is detectable from satellites optical sensors configuration.

\section{Simulations}

We now consider the simulations for all configurations of the satellites with optical sensors with following parameters: measurement period $T=1 \mathrm{~s}$, cone angle $\mathrm{FWHM}=10^{\circ}$, measurement error $\sigma_{\text {meas }}=5$ arcsec, maximal detectable magnitude $m_{\text {max }}=18$. Orbit parameters are represented in the section "Mission design".

An average detectable target debris is given following parameters: albedo $\xi=0.3$, cross-section $A=0.01 \mathrm{~m}^{2}$, velocity error $\sigma_{\mathbf{v}}=10^{-4} \mathrm{~m} / \mathrm{s}$, acceleration error $\sigma_{\mathrm{a}}=10^{-6} \mathrm{~m} / \mathrm{s}^{2}$. The orbit is chosen as the common debris-polluted LEO with parameters: SMA $a_{\text {targ }}=7177 \mathrm{~km}$, eccentricity $e_{\text {targ }}=10^{-6}$, inclination $i_{\text {targ }}=85.4^{\circ}, \operatorname{RAAN} \Omega_{\operatorname{targ}}=136.6^{\circ}, \mathrm{AOP}$ $\omega_{\text {targ }}=0$, TA $v_{\text {targ }}=300^{\circ}$.

Table 2. RMSE of the target debris position for sensor configurations with $\rho=1 \mathrm{~km}$

\begin{tabular}{|c|c|c|c|c|c|}
\hline \multirow{2}{*}{$\begin{array}{c}\text { Config- } \\
\text { uration }\end{array}$} & $\begin{array}{c}\text { Number } \\
\text { of } \\
\text { satel- } \\
\text { lites }\end{array}$ & $t=50 \mathrm{~s}$ & $t=100 \mathrm{~s}$ & $t=200 \mathrm{~s}$ & $t=300 \mathrm{~s}$ \\
\cline { 3 - 6 } Train & 2 & 1200 & 1050 & 280 & 200 \\
\cline { 2 - 6 } & 3 & 1070 & 730 & 220 & 190 \\
\hline \multirow{2}{*}{ GCO } & 2 & 1150 & 1000 & 380 & 200 \\
\cline { 2 - 6 } & 3 & 1100 & 700 & 220 & 160 \\
\hline $\begin{array}{c}\text { Tetra- } \\
\text { hedron }\end{array}$ & 4 & 820 & 660 & 210 & 200 \\
\hline
\end{tabular}


Table 3. RMSE of the target debris position for sensor configurations with $\rho=5 \mathrm{~km}$

\begin{tabular}{|c|c|c|c|c|c|}
\hline \multirow{2}{*}{$\begin{array}{c}\text { Configu- } \\
\text { ration }\end{array}$} & \multirow{2}{*}{$\begin{array}{c}\text { Number } \\
\text { of } \\
\text { satel- } \\
\text { lites }\end{array}$} & $t=50 \mathrm{~s}$ & $t=100 \mathrm{~s}$ & $t=200 \mathrm{~s}$ & $t=300 \mathrm{~s}$ \\
\cline { 3 - 6 } & 2 & 1300 & 970 & 300 & 180 \\
\hline \multirow{2}{*}{ Train } & 3 & 1080 & 900 & 300 & 170 \\
\cline { 2 - 6 } & 2 & 1200 & 920 & 230 & 210 \\
\hline \multirow{2}{*}{ GCO } & 3 & 900 & 550 & 220 & 170 \\
\hline $\begin{array}{c}\text { Tetra- } \\
\text { hedron }\end{array}$ & 4 & 800 & 790 & 230 & 170 \\
\hline
\end{tabular}

Table 4. RMSE of the target debris position for sensor configurations with $\rho=10 \mathrm{~km}$

\begin{tabular}{|c|c|c|c|c|c|}
\hline \multirow{2}{*}{$\begin{array}{c}\text { Configu- } \\
\text { ration }\end{array}$} & \multirow{2}{*}{$\begin{array}{c}\text { Number } \\
\text { of } \\
\text { satel- } \\
\text { lites }\end{array}$} & \multicolumn{4}{|c|}{ RMSE, m } \\
\cline { 3 - 6 } & 2 & 1250 & 1050 & 360 & 200 \\
\hline \multirow{2}{*}{ Train } & 3 & 1110 & 820 & 300 & 190 \\
\cline { 2 - 6 } & 2 & 1310 & 1100 & 260 & 180 \\
\hline \multirow{2}{*}{ GCO } & 3 & 980 & 680 & 260 & 170 \\
\cline { 2 - 6 } & 4 & 990 & 720 & 340 & 220 \\
\hline $\begin{array}{c}\text { Tetra- } \\
\text { hedron }\end{array}$ & 2 & & & & \\
\hline
\end{tabular}

a)

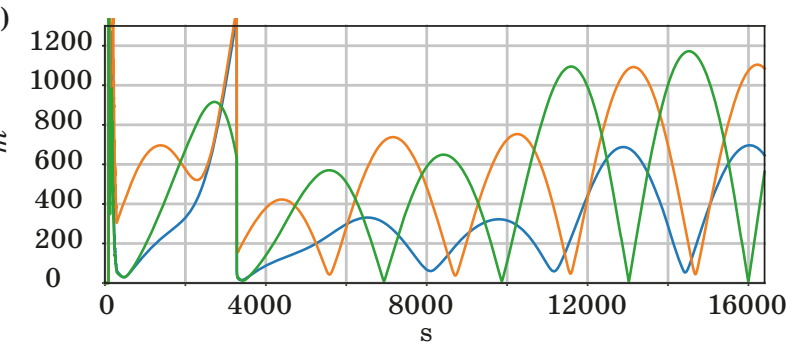

b)

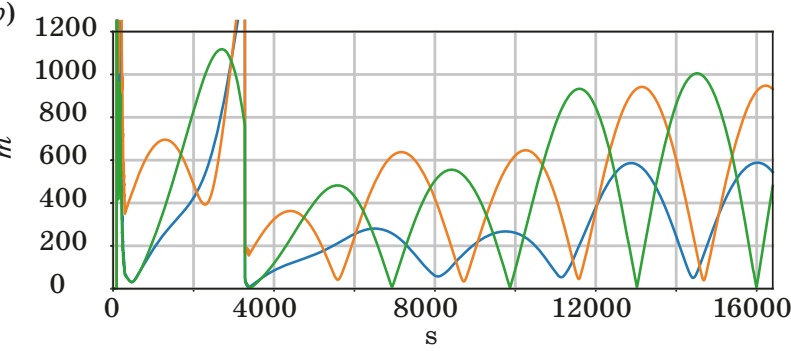

c)

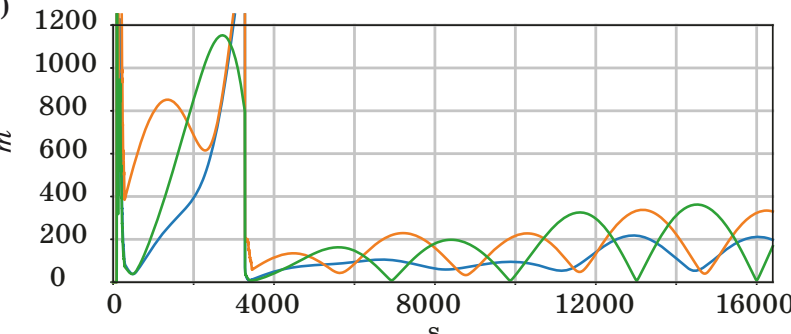

d)

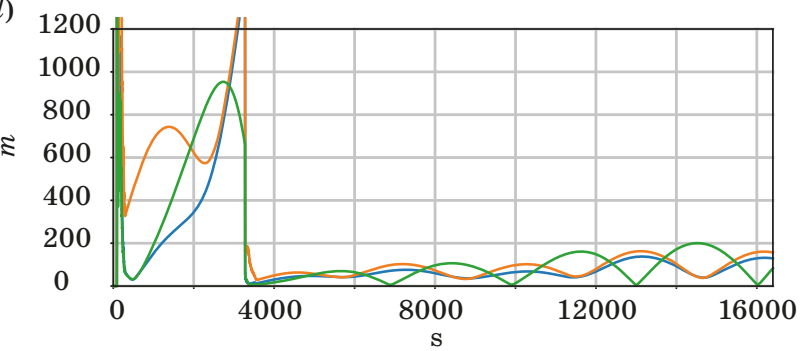

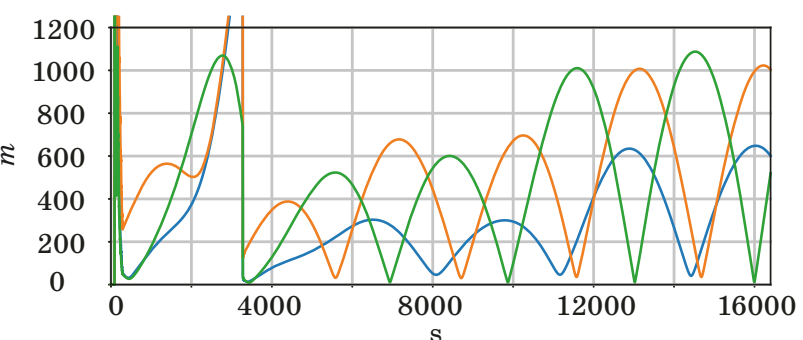
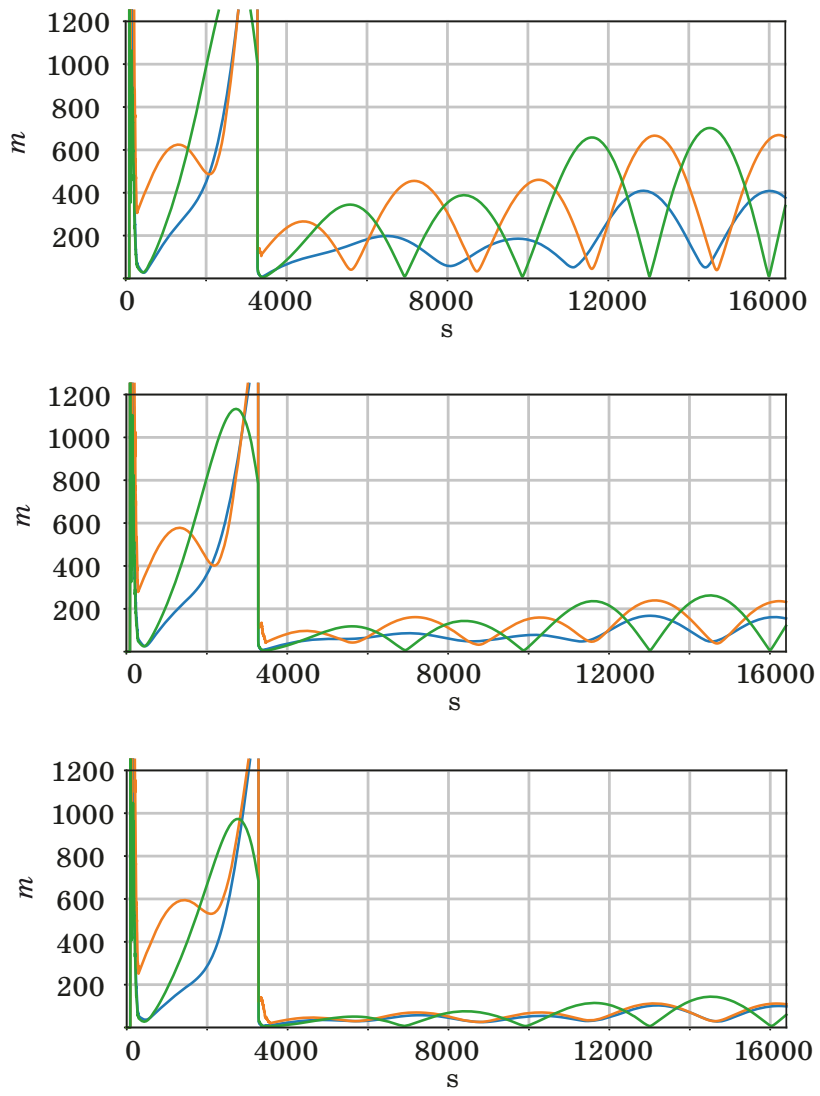

Z

- Fig. 3. RMSE of the target debris position determination vs time on orbit from 2 (left) and 3 (on right) optical sensors within satellites in GCO configuration with $\rho=1 \mathrm{~km}$ and measurement time of $t=50 \mathrm{~s}(a) ; t=100 \mathrm{~s}(b) ; t=200 \mathrm{~s}(c)$; $t=300 \mathrm{~s}(d)$ 
Simulations are held for $N=18000$ timesteps, with initial state covariance matrix for Extended Information Filter

$$
\mathbf{P}_{0}=\operatorname{diag}\left(\sigma_{r_{0}}^{2}, \sigma_{r_{0}}^{2}, \sigma_{r_{0}}^{2}, \sigma_{v_{0}}^{2}, \sigma_{v_{0}}^{2}, \sigma_{v_{0}}^{2}\right),
$$

where $\sigma_{r}=10 \mathrm{~km}$ and $\sigma_{v}=10 \mathrm{~m} / \mathrm{s}$. Initial state of the state-space vector $\mathbf{X}_{0}$ coincides with the true value of this vector (that's why the initial error on the graphs will be 0). Simulations are repeated $M=200$ times to calculate the round mean-squared error (RMSE) of the estimated position of the target debris.

The result of all simulations can be seen in tables 2-4. RMSEs are taken for each projection of the radius-vector of the target. It's clear, that's the biggest error is located in the $Z$-coordinate of the target position in all cases. Thus, we are putting it in the tables as the most appropriate one to show the effectiveness of the filter.

The example of RMSE simulations is given on Fig. 3, $a-d$.

Conclusions from these simulations are following:

1. The time of measurement dramatically decrease the error of the position determination for any sensors configuration in any size. For instance, the error for $t=50 \mathrm{~s}$ can reach up to $1.3 \mathrm{~km}$, while at $t=300 \mathrm{~s}$ the error decreases to $160 \mathrm{~m}$.

2. An amount of satellites also decreases the error of position estimation. So, for 2 satellites in small times of measurement RMSEs are actually worst. The situation flattens out as the time of observation increases - for times of $300 \mathrm{~s}$ errors for all different number of satellites are basically same, near $180 \mathrm{~m}$.

3. The type configuration seems to have rather low impact on the RMSE of the target position determination, but the results of simulations imply that GCO type of formation gives better results than the train type. Tetrahedral sensor composition is actually incomparable with that of GCO and train because of the different amount of satellites in those groups, but since this configuration is direct extension of GCO on the 4-point measurement sys- tem, we can claim that the tetrahedral formation is the best fit for our purposes. Thus, we recommend to use tetrahedral configuration in the problem of short-arc tracking of target debris.

\section{Conclusions}

The problem of space debris detection is highly relevant and focused by the modern community of researchers and engineers. One of the high priority problems in this area is to determine the orbit of the passing by piece of space debris with shorttrack measurements from the multipoint formation of the optical sensors, located in the group of satellites mainly on the sun-synchronous orbit. We managed to construct viable configurations for these sensors and compare the effectiveness in scenarios with different number of points of view (satellites) and measurement times. We implemented the extended information filter to make the simulations of the measurement of the target position by several optical sensors and calculated respective round mean-squared errors. The error diminishes when the number of sensors increases and also when the time of continuous measurement grows. The most important part is actually that the GCO configuration outstrips the train one in cases of 2 and 3 observation points, which means that the tetrahedral configuration, which is natural extension of GCO onto the case of 4 satellites, is the best usecase for determining the target debris orbit using short-arc optical measurements. The next step of this research is to collect enough statistics on the performance of this filter and configuration on the different orbits, different from sun-synchronous, and test whether it will be good enough without constant position near the terminator. The undeniable advantage of such research would be full coverage of LEO debris.

\section{Financial support}

The reported study was funded by RFBR, project 19-38-90278.

\section{References}

1. Kessler D. J., Cour-Palais B. G. Collision frequency of artificial satellites: the creation of a debris belt. $J$. Geophys. Res., 1978, vol. 83, A6, pp. 2637-2646. doi:10.1029/JA083iA06p02637

2. Oltrogge D. L., Alfano S. The technical challenges of better Space Situational Awareness and Space Traffic Management. Journal of Space Safety Engineering,
2019, vol. 6, iss. 2, pp. 72-79. doi:10.1016/j.jsse. 2019.05.004

3. Felicetti L., Emami M. R. A multi-spacecraft formation approach to space debris surveillance. Acta Astronautica, 2016, vol. 127, pp. 491-504. doi:10.1016/j. actaastro.2016.05.040

4. Flohrer T., Krag H., Klinkrad H., Schildknecht T. Feasibility of performing space surveillance tasks with a proposed space-based optical architecture, $A d$ - 
vances in Space Research, 2011, vol. 47, iss. 6, pp. 1029-1042. doi:10.1016/j.asr.2010.11.021

5. Jianli Du, Xiangxu Lei, Jizhang Sang. A space surveillance satellite for cataloging high-altitude small debris. Acta Astronautica, 2019, vol. 157, pp. 268275. doi:10.1016/j.actaastro.2019.01.003

6. Bin Li, Jizhang Sang, Junyu Chen. Achievable orbit determination and prediction accuracy using shortarc space-based observations of space debris. Advances in Space Research, 2018, vol. 62, iss. 11, pp. 30653077. doi:10.1016/j.asr.2018.08.038

7. Ansalone L., Curti F. A genetic algorithm for initial orbit determination from a too short arc optical observation. Advances in Space Research, 2013, vol. 52, no. 3, pp. 477-489. doi:10.1016/j.asr. 2013.04.004

8. Sciré G., Santoni F., and Piergentili F. Analysis of orbit determination for space based optical space surveillance systems. Advances in Space Research, 2015, vol. 56, no. 3, pp. 421-428. doi:10.1016/j. asr.2015.02.031

9. Felicetti L., Emami M. R. Attitude coordination of multiple spacecraft for space debris surveillance. Advances in Space Research, 2017, vol. 59, no. 5, pp. 1270-1288. doi:10.1016/j.asr.2016.12.012

10. Afanasev A., Shavin M., Ivanov A., Pritykin D. Tetrahedral satellite formation: Geomagnetic measurements exchange and interpolation. Advances in Space Research, 2021, vol. 67, iss. 10, pp. 3294-3307. doi:10.1016/j.asr.2021.02.012

11. Jia B., Pham K. D., Blasch E., Shen D., Wang Z., and Chen G. Cooperative space object tracking using space-based optical sensors via consensus-based filters. IEEE Transactions on Aerospace and Electronic Systems, 1936, vol. 52, no. 4, pp. 1908-2016. doi:10.1109/TAES.2016.140506

12. Sharma J. Space-based visible space surveillance performance. Journal of Guidance, Control, and Dynam- ics, 2000, vol. 23, no. 1, pp. 153-158. doi:10. $2514 / 2.4503$

13. Du J., Chen J., Li B., and Sang J. Tentative design of SBSS constellations for LEO debris catalog maintenance. Acta Astronautica, 2019, vol. 155, pp. 379388. doi:10.1016/j.actaastro.2018.06.054

14. Biktimirov S., Ivanov D., Sadretdinov T., Omran B., Pritykin D. A multi-satellite mission to illuminate the earth: Formation control based on impulsive maneuvers. Advances in the Astronautical Sciences, 2020, vol. 173, pp. 463-474.

15. Ivanov D., Biktimirov S., et al. Writing with sunlight: cubesat formation control using aerodynamic forces. Proceedings of the International Astronautical Congress, IAC 2019, October, 2019.

16. Battin R. H. An Introduction to the Mathematics and Methods of Astrodynamics. AIAA, 1999.

17. Stokes G. H., Braun C. V., Sridharan R., and Sharma J. The space-based visible program. Lincoln Laboratory Journal, 1998, vol. 11, no. 2, pp. 205-238. doi:10. 2514/6.2000-5334

18. Jia B., Ming X., and Cheng Y. Multiple sensor estimation using the sparse Gauss - Hermite quadrature information filter. 2012 American Control Conference (ACC), Montreal, QC, Canada, June 2012, pp. 55445549, doi:10.1109/ACC.2012.6315385

19. Chang L., Qin F., Li A., and Hu B. Unscented type Kalman filter: limitation and combination. IET Signal Processing, 2013, vol. 7, no. 3, pp. 167-176. doi:10.1049/iet-spr.2012.0330

20. Wang Y., Zheng W., Sun S., and Li L. Robust information filter based on maximum correntropy criterion. Journal of Guidance, Control, and Dynamics, 2016, vol. 39, no. 5, pp. 1126- 1131. doi:10.2514/1. G001576

21. Simon D. Optimal State Estimation: Kalman, $H$ Infinity, and Nonlinear Approaches. John Wiley and Sons, 2006. 552 p.

УдК 629.783

doi:10.31799/1684-8853-2021-4-37-46

Архитектура формаций кубсатов для наблюдения за малым космическим мусором и определения его орбиты

А. А. Афанасьев ${ }^{a}$, аспирант, orcid.org/0000-0001-7503-9696, anton.afanasev@skoltech.ru

Ш. Н. Биктимиров ${ }^{a}$, аспирант, orcid.org/0000-0003-0969-0944

${ }^{\mathrm{a}}$ Сколковский институт науки и технологий, Большой б-р, 30, стр. 1, Москва, 121205, РФ

Введение: спутники с сенсорами, которые встречают мусор, не могут отслеживать его на всей орбите из-за естественных ограничений оптических датчиков: поля зрения, затмения Земли, освещенности Солнцем. $K$ тому же время непрерывных наблюдений обычно очень невелико. В связи с этим представляется актуальным создание наиболее эффективной конфигурации оптических датчиков для обеспечения отслеживания короткой дуги орбиты целевого куска мусора с использованием масштабируемого обобщенного информационного фильтра. Цель: определить наилучший сценарий отслеживания орбиты космического мусора по короткой дуге с использованием многоточечных оптических датчиков. Результаты: выявлены оптимальные конфигурации группы спутников с оптическими датчиками, движущихся по солнечно-синхронной орбите. Смоделирован процесс определения орбиты мусора с помощью расширенного информационного фильтра с использованием измерений от многоточечных датчиков и вычислены среднеквадратические ошибки местоположения цели. На основе результатов моделирования для различных конфигураций, межспутниковых расстояний и времени измерения найден наиболее надежный сценарий из четырех спутников в тетраэдральной конфигурации, который рекомендуется использовать на практике отслеживания мусора по короткой дуге.

Ключевые слова - космический мусор, слежение на короткой дуге, солнечно-синхронная орбита, относительное движение, обобщенный информационный фильтр. 
Для цитирования: Afanasev A. A., Biktimirov S. N. CubeSats formation architecture for small space debris surveillance and orbit determination. Информационно-управляющие системы, 2021, № 4, с. 37-46. doi:10.31799/1684-8853-2021-4-37-46

For citation: Afanasev A. A., Biktimirov S. N. CubeSat formation architecture for small space debris surveillance and orbit determination. Informatsionno-upravliaiushchie sistemy [Information and Control Systems], 2021, no. 4, pp. 37-46. doi:10.31799/16848853-2021-4-37-46

\section{Финансовая поддержка}

Исследование выполнено при финансовой поддержке РФФИ в рамках научного проекта 19-38-90278.

\section{Уважаемые авторы!}

При подготовке рукописей статей необходимо руководствоваться следующими рекомендациями.

Статьи должны содержать изложение новых научных результатов. Название статьи должно быть кратким, но информативным. В названии недопустимо использование сокращений, кроме самых общепринятых (РАН, РФ, САПР и т. п.).

Текст рукописи должен быть оригинальным, а цитирование и самоцитирование корректно оформлено.

Объем статьи (текст, таблицы, иллюстрации и библиография) не должен превышать эквивалента в 20 страниц, напечатанных на бумаге формата A4 на одной стороне через 1,5 интервала Word шрифтом Times New Roman размером 13, поля не менее двух сантиметров.

Обязательными элементами оформления статьи являются: индекс УдК, заглавие, инициалы и фамилия автора (авторов), ученая степень, звание (при отсутствии - должность), полное название организации, аннотация и ключевые слова на русском и английском языках, ORCID и электронный адрес одного из авторов. При написании аннотации не используйте аббревиатур и не делайте ссылок на источники в списке литературы. Предоставляйте подрисуночные подписи и названия таблиц на русском и английском языках.

Статьи авторов, не имеющих ученой степени, рекомендуется публиковать в соавторстве с научным руководителем, наличие подписи научного руководителя на рукописи обязательно; в случае самостоятельной публикации обязательно предоставляйте заверенную по месту работы рекомендацию научного руководителя с указанием его фамилии, имени, отчества, места работы, должности, ученого звания, ученой степени.

Простые формулы набирайте в Word, сложные с помощью редактора Mathtype или Equation. Для набора одной формулы не используйте два редактора; при наборе формул в формульном редакторе знаки препинания, ограничивающие формулу, набирайте вместе с формулой; для установки размера шрифта в Mathtype никогда не пользуйтесь вкладкой Other, Smaller, Larger, используйте заводские установки редактора, не подгоняйте размер символов в формулах под размер шрифта в тексте статьи, не растягивайте и не сжимайте мышью формулы, вставленные в текст; пробелы в формуле ставьте только после запятых при перечислении с помощью Ctrl+Shift+Space (пробел); не отделяйте пробелами знаки: $+=-\times$, а также пространство внутри скобок; для выделения греческих символов в Mathtyре полужирным начертанием используйте Style $\rightarrow$ Other $\rightarrow$ bold.

Для набора формул в Word никогда не используйте вкладки: «Уравнение», «Конструктор», «Формула» (на верхней панели: «Вставка» - «Уравнение»), так как этот ресурс предназначен только для внутреннего использования в Word и не поддерживается программами, предназначенными для изготовления оригинал-макета журнала.

При наборе символов в тексте помните, что символы, обозначаемые латинскими буквами, набираются светлым курсивом, русскими и греческими - светлым прямым, векторы и матрицы - прямым полужирным шрифтом.

Подробнее см. pdf-файл «Правила подготовки рукописей» (стр. 11) на сайте https://guap.ru/ric

Иллюстрации:

- рисунки, графики, диаграммы, блок-схемы предоставляйте в виде отдельных исходных файлов, поддающихся редактированию, используя векторные программы: Visio (*.vsd, *.vsdx); Adobe Illustrator (*.ai); Coreldraw (*.cdr, версия не выше 15); Excel (*.xls); Word (*.docx); AutoCad, Matlab (экспорт в PDF, EPS, SVG, WMF, EMF); Компас (экспорт в PDF), веб-портал DRAW. IO (экспорт в PDF);

— фото и растровые - в формате *.tif, *.png с максимальным разрешением (не менее 300 pixels/inch).

Наличие подрисуночных подписей и названий таблиц на русском и английском языках обязательно (желательно не повторяющих дословно комментарии к рисункам в тексте статьи).

В редакцию предоставляются:

- сведения об авторе (фамилия, имя, отчество, место работы, должность, ученое звание, учебное заведение и год его окончания, ученая степень и год защиты диссертации, область научных интересов, количество научных публикаций, домашний и служебный адреса и телефоны, е-mail), фото авторов: анфас, в темной одежде на белом фоне, должны быть видны плечи и грудь, высокая степень четкости изображения без теней и отблесков на лице, фото можно представить в электронном виде в формате *.tif, *.png, *.jpg с максимальным разрешением - не менее 300 pixels/inch при минимальном размере фото $40 \times 55$ мм;

- экспертное заключение.

Список литературы составляется по порядку ссылок в тексте и оформляется следующим образом:

- для книг и сборников - фамилия и инициалы авторов, полное название книги (сборника), город, издательство, год, общее количество страниц, doi;

- для журнальных статей - фамилия и инициалы авторов, полное название статьи, название журнала, год издания, номер журнала, номера страниц, doi;

- ссылки на иностранную литературу следует давать на языке оригинала без сокращений;

- при использовании web-материалов указывайте адрес сайта и дату обращения.

Список литературы оформляйте двумя отдельными блоками по образцам lit.dot на сайте журнала (http://i-us.ru/paperrules): Литература и References.

Более подробно правила подготовки текста с образцами изложены на нашем сайте в разделе «Руководство для авторов» .

\section{Контакты}

Куда: 190000, Санкт-Петербург,

Б. Морская ул., д. 67, ГУАП, РИЦ

Кому: Редакция журнала «Информационно-управляющие системы»

Тел.: (812) 494-70-02

Эл. почта: ius.spb@gmail.com

Сайт: www.i-us.ru 